\title{
Predispositions and the Political Behavior of American Economic Elites: Evidence from Technology Entrepreneurs*
}

\author{
David E. Broockman ${ }^{\dagger}$ \\ Gregory Ferenstein \\ Neil Malhotra ${ }^{\S}$
}

September 14, 2018

\begin{abstract}
Economic elites regularly seek to exert political influence. But what policies do they support? Many accounts implicitly assume economic elites are homogeneous and that increases in their political power will increase inequality. We shed new light on heterogeneity in economic elites' political preferences, arguing that economic elites from an industry can share distinctive preferences due in part to sharing distinctive predispositions. Consequently, how increases in economic elites' influence affect inequality depends on which industry's elites are gaining influence and which policy issues are at stake. We demonstrate our argument with four original surveys, including the two largest political surveys of American economic elites to date: one of technology entrepreneurs - whose influence is burgeoning - and another of campaign donors. We show that technology entrepreneurs support liberal redistributive, social, and globalistic policies but conservative regulatory policies-a bundle of preferences rare among other economic elites. These differences appear to arise partly from their distinctive predispositions.
\end{abstract}

Replication Materials: The data, code, and any additional materials required to replicate all analyses in this article are available on the American Journal of Political Science Dataverse within the Harvard Dataverse Network, at: https://doi .org/10.7910/DVN/OGVWDE.

\footnotetext{
*This study was approved by the Stanford University Institutional Review Board (\#39512, \#38405, \#35267, and \#45302).

${ }^{\dagger}$ Assistant Professor of Political Economy, Stanford Graduate School of Business. dbroockmanestanford.edu

${ }^{\text {F}}$ Freelance Journalist. greg@greg ferenstein.com

${ }^{\S}$ Edith M. Cornell Professor of Political Economy, Stanford Graduate School of Business. neilmestanford.edu
} 
Concern over the political influence that American economic elites wield is one of the most significant and enduring foci of political science (e.g., Dahl 1961). Yet, we know remarkably little about what American economic elites actually want from government. Existing work often implicitly treats economic elites as homogenous, assuming that they largely support policies that would increase their wealth and exacerbate many forms of inequality (e.g., Bartels 2008; Hacker and Pierson 2017) 1 This view suggests a "vicious cycle" wherein economic inequality increases economic elites' political power, which in turn allows economic elites to advance policies that exacerbate economic inequality further still.

In this paper, we draw on the literature on mass political behavior and two of the largest surveys of American economic elites to date to advance a theoretical argument that sheds new light on heterogeneity in American economic elites' political preferences. Our argument, elaborated below, is that economic elites from an industry can share distinctive political preferences due in part to sharing distinctive political predispositions. We expect that, like the mass public, economic elites' political views are animated in part by values and predispositions that endure through adulthood (e.g., Berinsky 2017; Tesler 2015). Moreover, we expect that particular industries may attract individuals with distinctive predispositions, leading those in that industry to share a distinctive set of political views. The substantive implication of our argument is that we should not expect a simple, positive relationship between increases in the economic elites' political influence and the enactment of policies that exacerbate inequality. Rather, we should expect the impact of any growth in economic elites' influence on inequality to depend on which industry's rich are gaining influence and to vary by which policy area is at stake.

To test our argument and demonstrate its implications, we focus on technology entrepreneurs, a case study of major substantive significance. Technology entrepreneurs are well-positioned to exert large and growing political influence in American politics for four reasons.

\footnotetext{
${ }^{1}$ Due to space constraints, we discuss related studies and data collection efforts in Online Appendix D We also review related literature that has debated whether relatively affluent Americans are better represented or are more consistently conservative than others (e.g., Gilens and Page 2014, Enns 2015).
} 
First, they command growing personal wealth. Going forward, experts forecast that the technology industry will produce as many new millionaires as the financial industry. $\left.\right|^{2}$ They also comprise a burgeoning share of the ultra-wealthy: as Figure 1a shows, the share of the top 400 wealthiest Americans each year who made their money primarily in the technology sector has tripled over the last several decades..$^{3}$ Likewise, six of the ten wealthiest Americans made their money in technology $\left.\right|^{4}$ The American system of campaign finance makes this concentration of wealth especially consequential. For example, recent federal candidates have referred to Silicon Valley as a "political ATM"; the number of fundraisers sitting Presidents host in Northern California, home to Silicon Valley, is now greater than in more-populous Southern California 5

Second, technology entrepreneurs direct companies with enormous structural power over governments by virtue of their ability to direct investment and jobs (Lindblom 1977). These resources are significant. As of this writing (Q2 2018), the top five public corporations in the U.S. by market capitalization are technology companies: Apple, Amazon, Alphabet/Google, Microsoft, and Facebook. The average market capitalization of these five firms is more than twice as large as firms in other sectors that have been important to public policymaking such as financial services (JP Morgan Chase) and fossil fuels (ExxonMobil). Technology entrepreneurs have deployed their dominant economic positions to influence politics: for example, technology companies pressured the state of North Carolina to repeal a law that did not allow transgender people to use the bathroom that matches their gender identity ${ }^{6}$

Third, the ubiquitous presence of technology products in Americans' lives gives technology

\footnotetext{
2"World Wealth Report," Capgemini, https : / / www . worldwealthreport. com/uswr/download

${ }^{3}$ We thank Adam Bonica for sharing the Forbes 400 data, which is described in Bonica and Rosenthal (2015). The list of Forbes 400 individuals coded as technology entrepreneurs and their source of wealth is in Online Appendix I]

${ }^{4}$ These are Bill Gates, Jeff Bezos, Mark Zuckerberg, Larry Ellison, Larry Page, and Sergey Brin.

${ }^{5}$ See, e.g., "California's 'political ATM' is now located closer to San Francisco than L.A.," The Switch, https://www.washingtonpost.com/news/the-switch/wp/2014/09/10/californias-polit ical-atm-is-now-located-closer-to-san-francisco-than-l-a/

"Facebook, Apple, Google, and other tech CEOs demand North Carolina repeal anti-LGBT law" TechCrunch, https://techcrunch.com/2016/03/29/facebook-apple-google-other-tech-c eos-demand-north-carolina-repeal-anti-lgbt-law/
} 
entrepreneurs an unprecedented platform to influence and mobilize the public. The average American spends about a third of their waking hours using a computer or smartphone.7 This access to the public can be extraordinarily consequential. For example, in 2012, Google, Wikipedia, and other Internet companies asked visitors to their websites to contact Congress to oppose a pending bill, the Stop Online Piracy Act (SOPA), that would have made them liable for hosting copyright-infringing content. Congress received a deluge of opposition, leading Congressional support for the legislation to evaporate. 8

Fourth, millions of Americans work for companies technology entrepreneurs founded and run, and these numbers continue to swell: over half of US job growth from 2013 to 2015 was from firms in just four digital service areas. $9^{9}$ Employers can powerfully influence their employees' political behavior, and this leverage gives executives sway with officeholders (Hertel-Fernandez 2018).

Technology entrepreneurs appear especially well-positioned to use these resources to influence Democratic officeholders in particular. First, technology entrepreneurs are largely loyal to the Democratic party. For example, campaign contributions to Democrats from technology industry employees and ultra-wealthy technology entrepreneurs alike have long exceeded contributions to Republicans. Figures $1 \mathrm{~b}$ and $1 \mathrm{c}$ show trends in the share of contributions flowing to Democrats from, respectively, all individuals who work for technology companies and among just elite technology entrepreneurs who have ever been among the 400 wealthiest Americans in a given year. Figures $1 \mathrm{~d}$ and $1 \mathrm{e}$ show that the total amounts these populations have given to Democrats have also skyrocketed 10

As we show below, technology entrepreneurs also agree with typical Democratic party

\footnotetext{
7"AdReaction: Marketing in a multiscreen world," MillwardBrown, https: / / www. millwardbrown. com/ adreaction/2014/report/Millward-Brown_AdReaction-2014_Global.pdf.

"'SOPA protests shut down Web sites," Washington Post, https://wWw.washingtonpost.com/polit ics/2012/01/17/gIQA4WY16P_story.html.

"“America's advanced industries: New trends," Brookings, https://www.brookings . edu/research/a mericas-advanced-industries-new-trends/.

${ }^{10}$ This is not an artifact of technology entrepreneurs giving to local candidates in Democratic-leaning states, as patterns are similar at the presidential level.
} 
Figure 1: Technology entrepreneurs' wealth is growing, and they increasingly contribute it to Democrats.

(a)

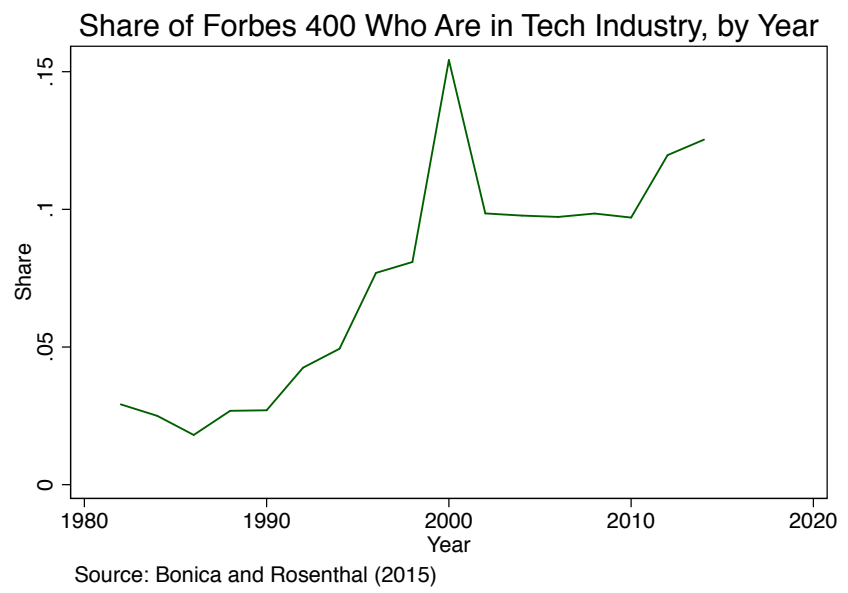

(b)

(c)

Share of Contributions Going to Democrats from All Those Working for Tech Companies, by Year

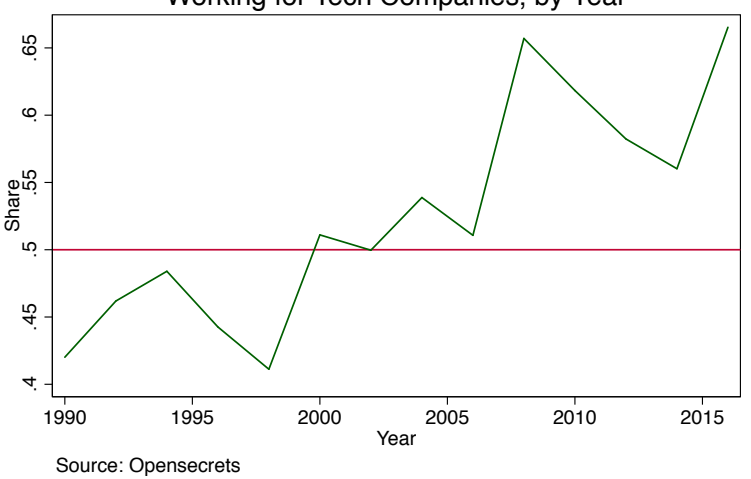

(d)

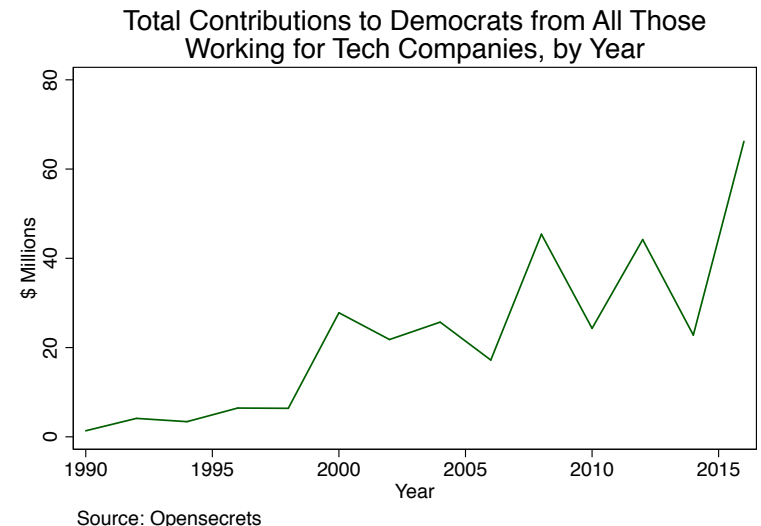

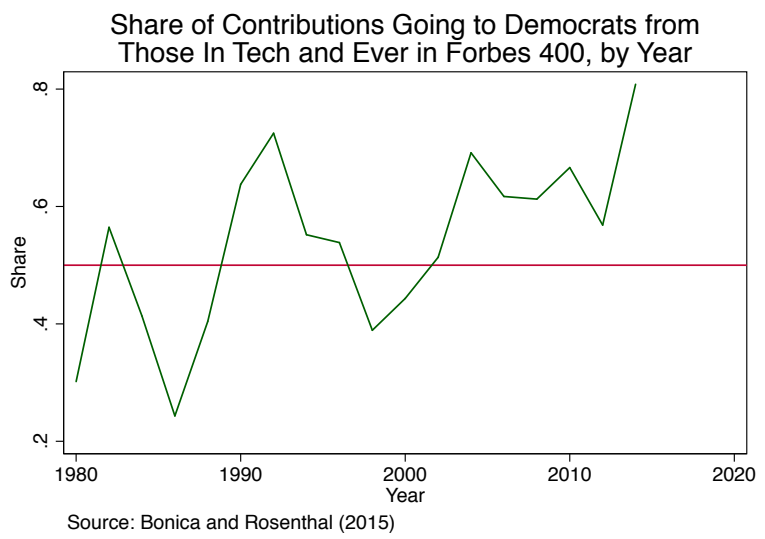

(e)

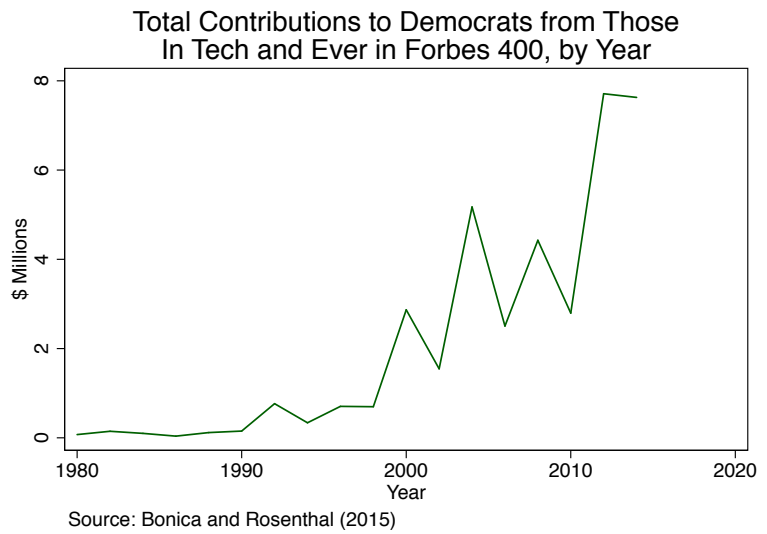


positions on most issues. But, crucially, this may not be the case for all issues. In the case of any such disagreements, theories of political development predict that as a powerful group aligned with a party sees its capacity to influence politics grow, it can steer that party's ideologies and platforms toward its policy views and priorities (e.g., Bawn et al. 2012; Schickler 2016).11 Figure 2 shows evidence from our survey of Democratic donors, described later, finds that elite Democratic donors expect exactly this to occur: technology entrepreneurs are one of the groups Democratic donors most expect to exert more influence with Democratic officeholders in the future, with a majority expecting their influence to grow. Almost no Democratic donors think technology entrepreneurs' influence will decline.

Figure 2: Democratic donors' forecasts of groups that will gain and lose influence in the party.

(a)

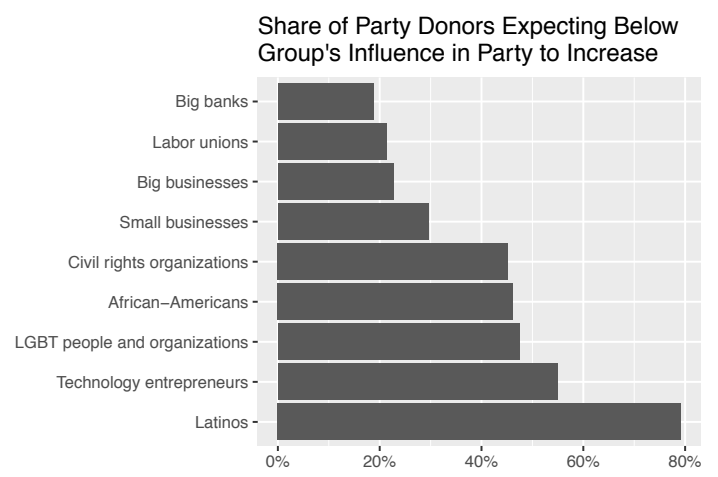

(b)

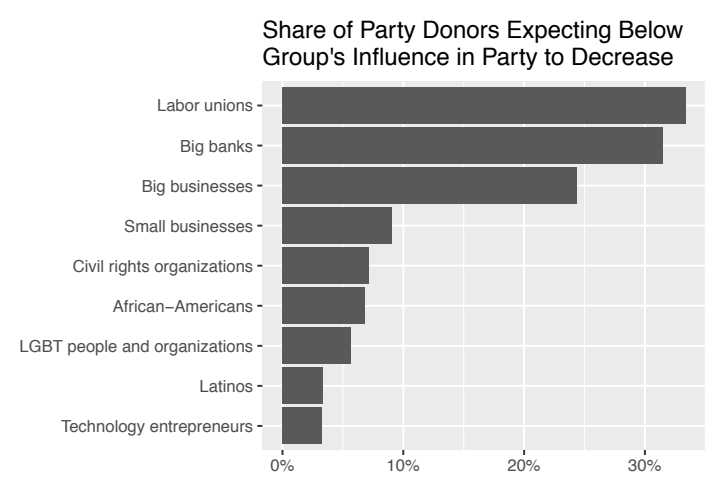

How will technology entrepreneurs use their growing capacity to influence politics, and especially Democratic politicians? Our theoretical argument generates new insights about the likely influence technology entrepreneurs will have on the Democratic party and therefore in American politics more generally. In particular, our argument predicts that it should matter that so

\footnotetext{
${ }^{11}$ Even if a group is relatively small or powerless to influence general elections, their influence over party nominations is thought to allow them to constrain elected officeholders and nominate those who support their group's priorities. Consistent with these qualitative findings, survey evidence shows that politicians almost always side their with copartisans, but that when rich and poor co-partisans disagree, politicians reliably side with their wealthy copartisans (Lax, Phillips and Zelizer 2017).
} 
many new economic elites come from this industry, as they may share a set of views that are distinct from existing American economic elites who hold sway with Democratic officeholders but who made their money in other industries, such as finance or law.

To test our theoretical argument and better understand this substantively important group, we conducted four original surveys, including the two largest political surveys of American economic elites to date. Whereas existing evidence in the literature on how economic elites shape political parties relies to a great extent on historical case studies, our surveys allow us to focus on a contemporary and developing case where we can collect quantitative data that opens the black box of an economic elite's political thinking. First, we surveyed nearly 700 elite technology entrepreneurs. The companies our survey respondents founded and led have raised more than $\$ 19.6$ billion in investment; most are millionaires (i.e., have a net worth over $\$ 1$ million) ${ }^{12}$ Second, we surveyed over 1,100 partisan donors. The respondents to this survey collectively contributed over $\$ 17.2$ million to campaigns since 2008 , and most were also millionaires. Finally, following most existing research on wealthy Americans' political views, we also examine self-identified wealthy respondents to an original survey of the general public. Comparing these groups of wealthy individuals to technology entrepreneurs allows us to test our argument about differences between the wealthy in general and economic elites in particular industries.

Later we also present an original survey of undergraduate students from Stanford University, which graduates more technology company founders than any other US university. ${ }^{13}$ This survey joins other evidence we present consistent with technology entrepreneurs sharing distinctive predispositions, as students majoring in computer science who are likely to join the technology

\footnotetext{
${ }^{12}$ We explicitly defined "millionaire" for respondents as having a net worth over $\$ 1$ million, although it is possible some respondents misunderstood the question as referring to annual income. Any such respondent misunderstanding would lead us to understate how elite our samples are, as there are even fewer Americans that have annual incomes over \$1 million than a net worth this high. Nevertheless, although having \$1 million in net assets does not necessarily make one extremely wealthy, this does put one in the top $4 \%$ of adults and therefore represents a reasonable threshold to assess the face validity of the sample.

13“These schools graduate the most funded startup CEOs", TechCrunch, https://techcrunch.com/2018/ 05/12/these-schools-graduate-the-most-funded-startup-ceos/
} 
industry in the future already exhibit many of the same views as technology company founders - even though their peers majoring in biology do not.

These data produced two surprising and substantively significant findings that are consistent with our theoretical argument that economic elites from an industry can share a distinctive set of political preferences due in part to sharing a distinctive set of political predispositions.

First, although technology entrepreneurs overwhelmingly support Democrats, most of these economic elites elites share a particular and unique set of views across policy domains, being conservative in some important areas. In particular, on issues related to economic redistribution, globalization, and social issues, technology entrepreneurs are typically as or more liberal than Democratic citizens, Democratic wealthy individuals, and Democratic donors; they are also more liberal on all these issues than millionaires in the mass public. However, despite their liberalism on economic redistribution, technology entrepreneurs are very conservative on issues of government regulation. Indeed, technology entrepreneurs' views on regulation closely resemble those of Republican donors. Technology entrepreneurs are also more conservative than millionaires in the mass public on issues of regulation, despite being more liberal than millionaires in other domains. This pattern is surprising in light of popular accounts that describe technology entrepreneurs as falling within categories familiar in American politics: as typically liberal, typically conservative, or typically libertarian. None of these traditional categories captures their views; we show that technology entrepreneurs hold a distinctive set of views uncommon among any other mass or elite group we examined.

Our second set of findings concerns evidence consistent with our theoretical argument for why economic elites such as technology entrepreneurs hold the views that they do. Consistent with our theoretical argument, we show that technology entrepreneurs share a distinct pattern of values and predispositions that correspond with their views in related policy domains. Most importantly, with a series of pre-registered comparisons and survey experiments, we show that technology entrepreneurs' opposition to government regulation can be traced at least partly to positive 
predispositions towards markets and entrepreneurship_-predispositions we also show are already evident in a sample of undergraduate computer science majors who have demonstrated interest in joining the industry in the future. We also show that demographics, geography, and economic interests cannot completely explain these differences. This is not to say that the economic interests of the technology industry are not important for understanding its anti-regulation attitudes, but that values and predispositions are also important explanatory factors above and beyond narrow financial concerns.

Our findings make two main contributions. Theoretically, we illuminate important heterogeneity in economic elites' political views. Although we are not the first to suggest that economic elites are not homogeneous in their political preferences, surprisingly little prior work has actually theorized or documented the origins or nature of their heterogeneity. Our argument about political predispositions provides new ways to understand this heterogeneity. This has important implications for understanding how rising economic inequality impacts politics: we offer new predictions for how it matters which industries' economic elites are gaining influence, as well which policy domains are at stake.

Substantively, our findings also provide new insights into the future of American politics. On the one hand, as technology entrepreneurs gain wealth and influence, they may potentially serve as an unexpected source of support for liberal policies in many domains by becoming a key source of financial support for the Democratic Party. On the other hand, as they gain influence within the Democratic Party - as Democratic donors expect them to- their conservative views on issues surrounding labor unions and labor market regulation appear likely to lead the Democratic Party in new directions, with mixed implications for inequality. We return to this in the discussion. 


\section{The Political Behavior of American Economic Elites}

\section{Theoretical Argument}

We draw on the literature on mass political behavior to argue that economic elites from an industry can share distinctive political preferences due in part to sharing a distinctive set of political predispositions. Our argument begins with the expectation that economic elites should be similar to the mass public in that their political views stem in part from a broad suite of values and predispositions that endure through adulthood (e.g., Berinsky 2017; Gerber et al. 2010; Sears and Funk 1999; Tesler 2015).14

We further expect that those who choose to work in particular industries may tend to share a common set of these predispositions. This is because predispositions that affect people's political views are also thought to guide their choices in non-political domains (e.g., Feldman and Stenner 1997). For example, individuals low in authoritarianism place higher value on curiosity; we would therefore expect them to be more attracted to careers in industries such as technology and academia and to succeed in these industries. Their common experiences working in an industry may also affect their shared predispositions.

We finally expect that any predispositions economic elites in an industry share should also lead them to share certain political views. Moreover, depending on the particular set of predispositions, the overall amalgam of policy views the wealthy in an industry exhibit may not cleanly map to traditional political categories or a single position on a left-right continuum. Political behavior research on the mass public not only suggests that people's predispositions inform their policy preferences; each predisposition is thought to inform people's policy preferences in specific domains (Tesler 2015). For example, authoritarianism especially informs

\footnotetext{
${ }^{14}$ These predispositions could influence even rational individuals' political attitudes and behaviors in the presence of strong self-interest when individuals gain expressive benefits from acting in accordance with their predispositions about what is proper and the probability that their choices affect outcomes is sufficiently low (Feddersen, Gailmard and Sandroni 2009).
} 
attitudes on social issues (Stenner 2005). As a result, an industry that selects for individuals low in authoritarianism but with other predispositions that incline them towards conservative views may have a particular mix of liberal views on social issues and conservative views on other issues.

The substantive implication of our argument is that we should not expect a simple, positive relationship between increases in economic elite's political influence and the enactment of policies that exacerbate inequality. Rather, we should expect the impact of any growth in the economic elite's influence on inequality to depend on which industry's rich are getting more influential and to vary by which policy area is at stake.

\section{Applying Our Argument to Technology Entrepreneurs}

Applying our argument to technology entrepreneurs, we hypothesized in a pre-analysis plan $[15$ that technology entrepreneurs would share a distinctive set of values and predispositions that would correspond with a distinctive set of political views. We consider views in four main policy domains: redistribution, regulation, globalization, and social issues. To form our specific empirical hypotheses regarding technology entrepreneurs' views in these domains, we examined the political behavior literature to identify predispositions that: (1) strongly correlated with these policy attitudes; and (2) based on our qualitative analysis were prevalent among technology elites. We then selected survey items used by previous research to measure the predispositions, choosing those that have been found to have high construct validity and reliability.

We first hypothesized that technology entrepreneurs would be low in authoritarianism, a predisposition that should incline them to be liberal on social issues. Historians have noted that the contemporary American technology industry emerged out of countercultural movements in the 1950s and 1960s and continues to attract individuals comfortable with questioning established social hierarchies and arrangements given the disruptive power of many technologies (Markoff

\footnotetext{
${ }^{15} \mathrm{We}$ pre-registered our predictions and how we would test them in a pre-analysis plan, described in Online Appendix J before collecting the confirmatory dataset described below that we use to test our hypotheses. The undergraduate survey was inspired by reviewer comments and therefore not part of the pre-analysis plan.
} 
2005). Authoritarianism involves punitiveness towards those who differ from established norms and as a result has been found to robustly predict conservative attitudes on social issues such as abortion and gay rights (Hetherington and Weiler 2009, Stenner 2005).

Second, we expected technology entrepreneurs to be highly cosmopolitan, following the work of Jackman and Vavreck (2011), who define cosmopolitans as people who embrace "things and people who are different," and "whose conception of community is much more broad" (i.e., global) (p. 72). We expected those who self-select into and lead the technology industry, which is highly racially diverse and globally integrated, to share this predisposition. Following Jackman and Vavreck (2011), we therefore predicted that technology entrepreneurs would place comparatively high weight on the welfare of non-Americans across the globe. For example, we expected them to support concentrating on problems faced by those abroad and not just problems here at home, to support free trade, and to allow much greater immigration $\sqrt{16}$ Technology elites may, of course, also have economic rationales for supporting increased trade and high-skilled immigration.

Third, we expected technology entrepreneurs to be low in racial resentment given the relatively high racial diversity of the educational settings where technology entrepreneurs receive their training and the geographic areas where they typically live. Those high in racial resentment should be less likely to select into these experiences or to have this predisposition changed over time as a result of contact with outgroups. Research indicates that Americans' attitudes towards taxing and spending are highly influenced by their views towards the racial minorities they see as beneficiaries of much of that spending (e.g., Gilens 1999; Tesler 2012). We therefore expected technology entrepreneurs to be relatively friendly towards taxation and redistribution-in favor of reducing economic inequality. ${ }^{17}$

\footnotetext{
${ }^{16}$ See also "Ordering vindaloo or hunting for vension," The Upshot, https://www. nytimes.com/2017/ 02/28/upshot/ordering-vindaloo-or-hunting-for-venison-how-you-vote.html

${ }^{1 /}$ Although this might go against their personal economic interests in the form of higher taxation, it is also possible that a stronger safety net may strengthen overall societal human capital and therefore benefit the industry.
} 
With this said, we did not expect that technology entrepreneurs would simply look like liberal Democrats in every single domain. We also predicted that technology entrepreneurs would be more hostile than other Democrats towards government regulation. Their industry's interests certainly favor these views in many cases, but we also expected individuals who select into entrepreneurship to have positive predispositions towards markets and entrepreneurs, which would make them wary of government constraining markets and entrepreneurs in these areas. Later, we present survey experiments and other theoretically informative comparisons that suggest that these predispositions play an important role in informing technology entrepreneurs' views on regulation.

\section{Data: Original Surveys}

We tested our hypotheses with surveys of technology entrepreneurs, partisan donors, and the mass public we conducted during the last week of February 2017. Nearly all respondents to all three surveys completed their responses during that week. This means we can rule out that any differences between the groups are due to reactions to different contemporaneous political events. The undergraduate survey we discuss later was conducted in March 2018.

\section{Survey of Technology Entrepreneurs}

We exploit the existence of a unique sampling frame to study technology entrepreneurs: Crunchbase, a professionally run, comprehensive database of individuals in the technology industry. We gathered a random sample of 8,499 individuals listed as founders or CEOs of companies in Crunchbase in 2013. We conducted several small, exploratory surveys of random subsamples of these individuals to formulate our hypotheses and register them in a pre-analysis plan. We next attempted to survey an independent group of 4,245 individuals in this frame to test our hypotheses. This survey received 691 responses, a response rate of $16 \% .18$ We only analyze data from US citizens and residents, which excludes 88 respondents.

\footnotetext{
${ }^{18}$ For further discussion of survey response rates, see Online Appendix E.1
} 
Our survey appears to have successfully captured elite technology entrepreneurs. Data from the sampling frame indicates that the company founded or led by the median respondent raised well over $\$ 1,000,000$ in venture capital funding, with many having raised substantially more (see Online Appendix E.2.1). Figure 3 shows that the modal US respondent indicated they were a millionaire who founded and runs a company in the technology industry with approximately 100 employees.

Figure 3: Self-reported respondent characteristics: technology entrepreneur survey.

(a)

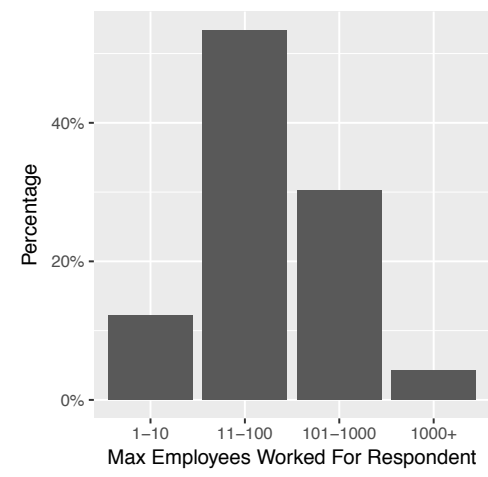

(c)

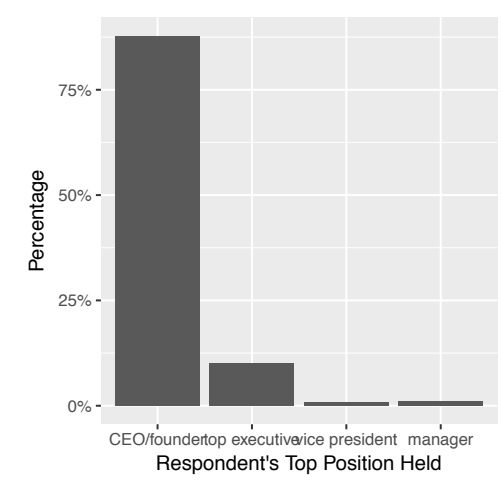

(d)

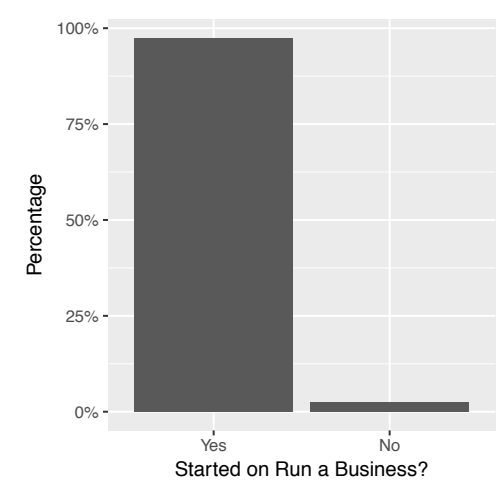

(b)

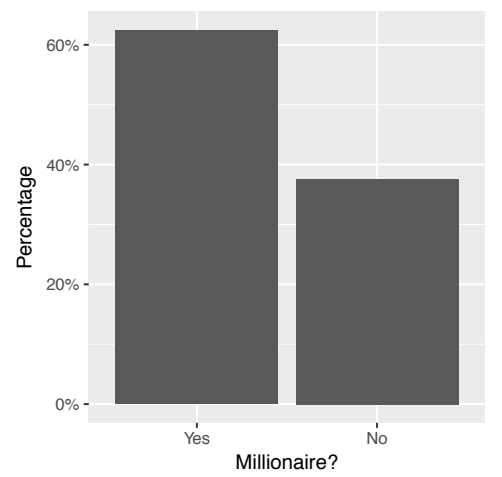

(e)

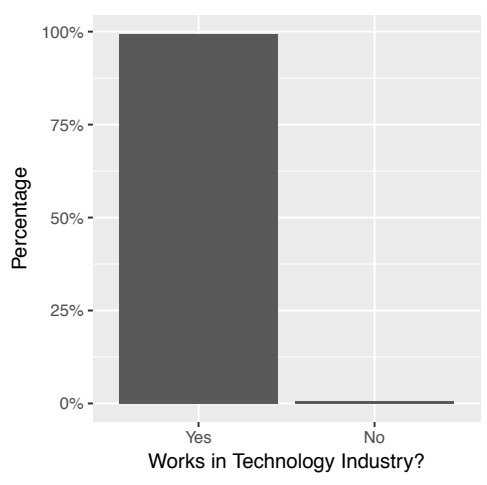

\section{Survey of Partisan Donors}

To compare the pressures technology entrepreneurs will place on politicians with the pressures politicians are currently experiencing from economic elites in their party (Lax, Phillips and Zelizer 
2017), we also conducted an original survey of partisan donors with a substantial oversample of the top $1 \%$ of donors.19 1,152 of the 16,400 donors we sampled completed the survey, a response rate of about $7 \%$, which is slightly higher than similar surveys of the mass public recruited to online surveys by mail and comparable to telephone surveys of the mass public 20

We appear to have successfully captured elite donors with this survey. In total, the respondents to this survey have donated over $\$ 17.6$ million to the political parties since 2008. A majority identified as millionaires.

\section{Wealthy Individuals and Partisans in the Mass Public}

As a further comparison, we gathered 1,636 survey responses from the mass public from Survey Sampling International. This large sample size means that we have reasonably sized subsamples of Americans who identify as Democrats, as Republicans, and as millionaires (4.4\% of the sample identified as such). We quota-sampled to achieve benchmarks on education, gender, race, and party identification.

\section{Representativeness}

Due to space constraints, we present data on the representativeness of these three samples in Online Appendix E.2. We find that these samples are generally closely representative of their sampling frames on many characteristics. The two exceptions are that the technology entrepreneur sample underrepresents companies that shut down (likely because they no longer were reachable at the same e-mail addresses) and that very large donors were less likely to respond to the donor survey. Thankfully, we oversampled very large donors in anticipation and so still have responses from many of them. Online Appendix Section C.3 also shows versions of our main analyses that weight all respondents by all the characteristics we describe in Appendix E.2; the results do not change.

\footnotetext{
${ }^{19}$ Online Appendix E.3 discusses how we defined this sampling frame and our mail-to-online survey procedure.

${ }^{20}$ See Online Appendix E.1.
} 


\section{Descriptive Results}

\section{Technology Entrepreneurs' Support for Democratic Candidates and Many Liberal Policies}

To motivate our main analyses, we first show that most technology entrepreneurs support Democratic candidates and liberal policies in most policy domains.

First, the partisan orientations of the technology entrepreneurs in our sample are clear: the technology entrepreneurs who responded to our survey lean heavily Democratic. $75.2 \%$ indicated that they supported Hillary Clinton in the 2016 Presidential election, versus only $8.8 \%$ who supported Donald Trump. 61.3\% of technology entrepreneurs in our survey identify as Democrats versus only $14.1 \%$ who identify as Republicans. As mentioned above, these findings are not artifacts of our sample or cheap talk on surveys, as similar patterns emerge in campaign donations.

Next, to characterize their views on issues, we show results for indices we formed by combining related survey items in each of four policy areas. We combine the items by rescaling each to $0-1$ and then taking the average of these items, such that the most liberal possible pattern of responses across all items within a domain would yield a 1 and the most conservative a 0 . We exclude missing and don't-know responses.21

As we expected, technology entrepreneurs have liberal views in many policy domains. Figure 4 illustrates the results, showing averages of each scale along with 95\% confidence intervals among (a) the entire public, (b) just those in the public who identify as Democrats.22 (c) just those people

\footnotetext{
${ }^{21}$ Our pre-analysis plan, given in Online Appendix J] specified which survey items we would combine into each index and gives the item wordings. Table 1 gives a summary of the items we use to form each of the four scales. Online Appendix B gives the marginal distribution on every item by group, organized by policy area, and shows that the results are similar for the individual items. Because the differences we discuss are usually large, much of the paper focuses on visual presentation of the results. Throughout the paper we will also report two-tailed $p$-values on the numerical differences we discuss. Online Appendix C also presents regression models that formally test the relevant hypotheses about differences between the groups we discuss, as laid out in our pre-analysis plan.

${ }^{22}$ We ask the standard ANES party identification question and include leaners as partisans.
} 
Table 1: Summary of Survey Items in Each Policy Scale

\begin{tabular}{|c|c|}
\hline Social Issues & Globalism \\
\hline $\begin{array}{l}\text { - Same-sex marriage. } \\
\text { - View on abortion (scale with options). } \\
\text { - Gun control. } \\
\text { - Death penalty. }\end{array}$ & $\begin{array}{l}\text { - Pay less attention to problems overseas } \\
\text { and concentrate on problems at home. } \\
\text { - In trade agreements, prioritize } \\
\text { American jobs over foreign jobs. } \\
\text { - Ideal immigration policy (scale with } \\
\text { defined options). } \\
\text { - Free trade agreements are a good thing. }\end{array}$ \\
\hline Redistribution & Regulation \\
\hline $\begin{array}{l}\text { - Support for universal healthcare, even if } \\
\text { means raising taxes. } \\
\text { - Support programs benefiting only poorest } \\
\text { Americans. } \\
\text { - Support taxes on those making }>\$ 250 \mathrm{k} \\
\text { per year. } \\
\text { - Support taxes on those making }>\$ 1 \mathrm{MM} \\
\text { per year. } \\
\text { - Increase federal spending on the poor. }\end{array}$ & $\begin{array}{l}\text { - Regulate Uber like taxis. } \\
\text { - Regulate 'gig' workers like regular } \\
\text { workers. } \\
\text { - It is too hard to fire workers. } \\
\text { - Government regulation of business does } \\
\text { more harm than good. } \\
\text { - Regulations on drones, self-driving } \\
\text { cars, and internet companies (separate } \\
\text { items).* }\end{array}$ \\
\hline
\end{tabular}

*Later we show that our results are similar on views on the regulation of three non-technology industries.

in the public who identify as Democrats and have college degrees ${ }^{23}$ (d) just Democratic donors, (e) just those in the public that identify as Republicans, (f) just Republican donors, and, finally, (g) technology entrepreneurs. Online Appendix F shows a comparison with millionaires in the mass public.

First, technology entrepreneurs are the most pro-globalism of any of the groups save for Democratic donors $(0.14$ to 0.36 scale points greater than the other groups, $p<0.01$ for all comparisons). For example, they are the most likely to say that trade policy should prioritize the well-being of those abroad instead of Americans (with 44\% agreeing), to disagree that we should pay less attention to problems overseas (with 53\% disagreeing), and to support free trade

\footnotetext{
${ }^{23}$ We conduct this comparison to show that technology entrepreneurs' set of views does not simply reflect the fact that they are educated Democrats; they are distinct from other educated Democrats.
} 
agreements (87\%). $56 \%$ favor increasing levels of immigration, essentially equal to Democratic donors and more than any other sample, including 15 points higher than Democratic citizens $(p<0.01)$. All these policy views militate in favor of greater global equality.

Figure 4: Average of Policy Indices by Area

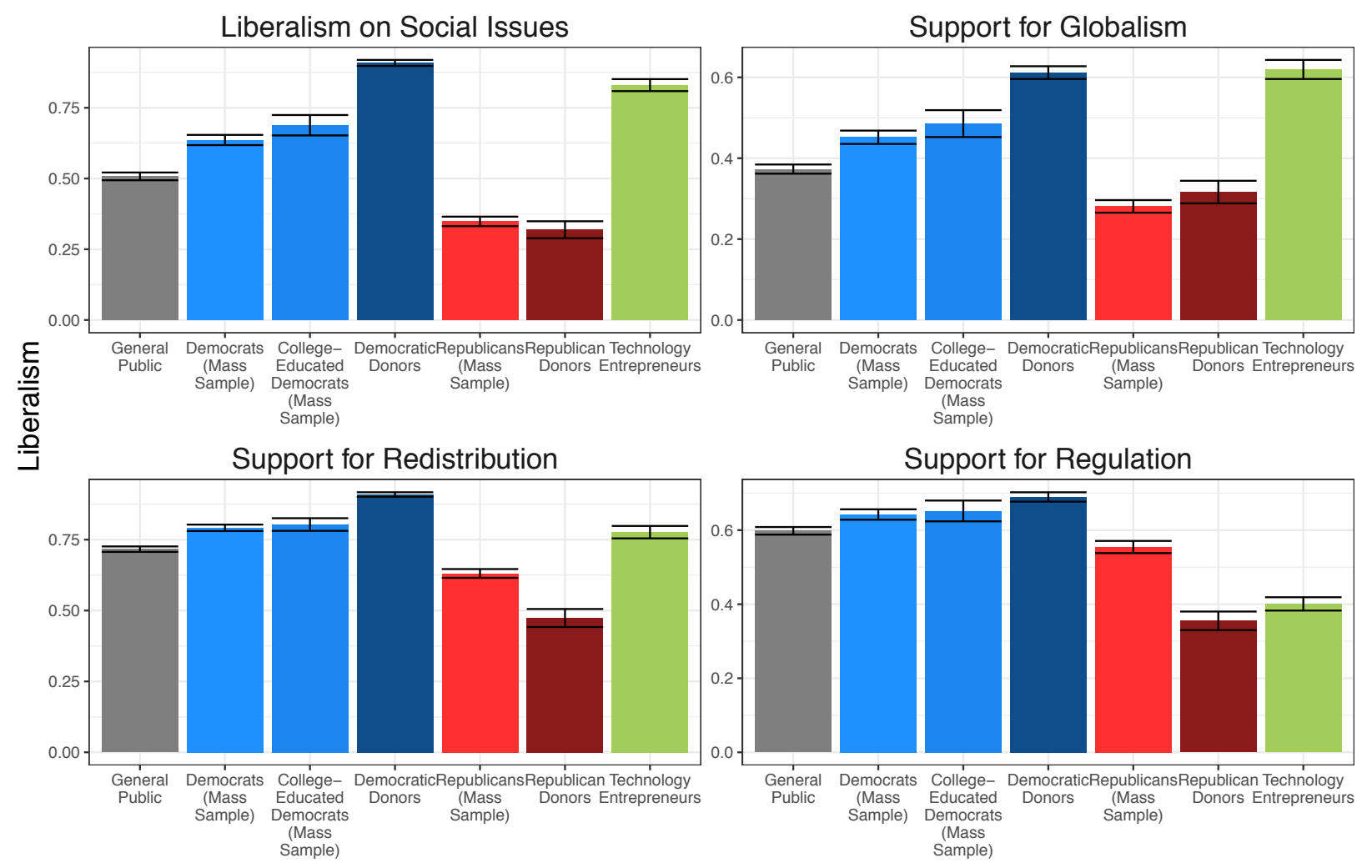

On social issues, technology entrepreneurs are again very liberal—as liberal as Democratic donors and more so than Democratic citizens $(0.19$ scale points greater, $p<0.01)$. They nearly universally support same-sex marriage (96\%), favor gun control (82\%), oppose the death penalty $(67 \%)$, and view abortion as a matter of personal choice $(79 \%)$.

Finally, and perhaps most surprisingly, technology entrepreneurs strongly support redistribution and taxation. They appear similar to Democratic citizens and donors on these items and more liberal than independent citizens, Republican citizens, and Republican donors $(p<0.01$ for all three comparisons). For example, nearly all technology entrepreneurs support increasing 
taxes on those making over $\$ 250,000$ or $\$ 1,000,000$ per year (with $76 \%$ and $83 \%$ expressing some support for each, respectively, and a majority expressing "strong" support for both). 75\% support federal spending on programs that benefit only the poor and 59\% think such spending should be increased. $82 \%$ indicate support for universal healthcare even if it means raising taxes, with a majority again offering "strong" support for this proposition. Only small minorities of technology entrepreneurs want federal spending on the poor to decrease $(6 \%)$, and only $6 \%$ of technology entrepreneurs strongly disagree that the government should ensure universal healthcare coverage, the category into which a majority of Republican donors fall. These patterns are also evident when comparing technology entrepreneurs and millionaires in the mass public; technology entrepreneurs are more liberal than millionaires in the mass public in all three of these domains ${ }^{24}$

Technology entrepreneurs' strong support for taxing the wealthy and for redistribution may be surprising in light of accounts that depict them as libertarians (e.g., Hacker and Pierson 2017, p. 189). Table 2, however, shows that, relative to the other samples, technology entrepreneurs are actually unusually unlikely to agree with a description of libertarian philosophy.25 Although technology entrepreneurs share certain views associated with libertarianism, their liberal views on economic redistribution belie this characterization.

Other data we collected suggests that these liberal attitudes matter to technology entrepreneurs. When we asked technology entrepreneurs on one of our preliminary surveys to pick three policy areas that were most important to them, they were even more likely than the general public to select areas related to public goods provision, such as education, the environment, public infrastructure, and health care. They were, if anything, less likely to list taxes as representing an important problem (see Online Appendix G).

\footnotetext{
${ }^{24}$ See Online Appendix F Online Appendix C.3 also presents weighted versions of these analyses; the results are essentially identical.

${ }^{25}$ In pilot surveys, we likewise found that very few technology entrepreneurs explicitly self-identify as libertarians.
} 
Table 2: Technology Entrepreneurs Do Not Agree with Libertarian Philosophy

\begin{tabular}{lccccc} 
& $\begin{array}{c}\text { Technology } \\
\text { Entrepreneur } \\
\text { Survey }\end{array}$ & $\begin{array}{c}\text { Democratic } \\
\text { Donor } \\
\text { Survey }\end{array}$ & $\begin{array}{c}\text { Republican } \\
\text { Donor } \\
\text { Survey }\end{array}$ & $\begin{array}{c}\text { Democrats } \\
\text { (Public } \\
\text { Survey) }\end{array}$ & $\begin{array}{c}\text { Republicans } \\
\text { (Public } \\
\text { Survey) }\end{array}$ \\
\hline $\begin{array}{l}\text { Agree With } \\
\text { Libertarian } \\
\text { Philosophy }\end{array}$ & $23.5 \%$ & $5.1 \%$ & $68.4 \%$ & $43.8 \%$ & $62.5 \%$ \\
\hline
\end{tabular}

Notes: Data from our technology entrepreneur, and mass public surveys. The surveys asked whether individuals agreed or disagreed with the statement "I would like to live in a society where government does nothing except provide national defense and police protection, so that people could be left alone to earn whatever they could." This question wording is from Page, Bartels and Seawright (2013). Cell probabilities above give the percent that either somewhat or strongly agreed.

\section{Technology Entrepreneurs Typically Oppose Regulation Despite Their Other}

\section{Liberal Views}

The results we have presented so far could be easily explained by the theory that technology entrepreneurs are Democrats and so tend to have liberal views on policy issues generally. However, as a reminder, our theoretical argument predicted that economic elites in a particular industry - due in part to their shared predispositions - may share a set of political views that is highly distinctive. Our first main result is that technology entrepreneurs are in fact distinctive, being very conservative within the specific issue domain of regulation-particularly of labor markets.

Technology entrepreneurs' conservative views on regulation can be seen in the bottom right panel of Figure 4. Despite having views similar to wealthy Democrats in most policy domains, including economic redistribution, technology entrepreneurs do not share conventional Democratic views on the regulation of product and labor markets. Technology entrepreneurs are indeed more conservative even than Republican citizens (by 0.15 scale points, $p<0.01$ ) and most similar to Republican donors (who are only 0.05 scale points higher). For example, technology entrepreneurs 
almost all believe, much like Republican donors and citizens, that it is too difficult to fire workers and that the government should make it easier to do so (82\%). However, majorities of Democratic donors and citizens believe the government should make it harder to fire workers (a 50 percentage point difference from technology entrepreneurs, $p<0.01$ ). Consistent with this difference, $74 \%$ of technology entrepreneurs say they would like to see labor unions' influence decrease, versus only $18 \%$ of Democratic donors and $33 \%$ of Democratic citizens ( $p<0.01$ in both cases).

Technology entrepreneurs are also less likely than Democrats to support regulation in product markets, and much more likely to believe that government regulation of business does more harm than good (for individual items, see Figure OA7; differences between 17 and 19 percentage points relative to Democratic donors; $p<0.01$ for all comparisons). For example, technology entrepreneurs, like Republicans, believe the government should not strictly regulate Uber like taxis $(70 \%)$. Democratic citizens and donors, however, do not agree (30-32 percentage point differences, $p<0.01)$.

Technology entrepreneurs are also more conservative than even millionaires in the mass public on matters of regulation, even though they are more liberal than millionaires in the mass public in other domains. These findings hold even when we compare millionaire technology entrepreneurs to millionaires in the mass public. ${ }^{26}$

Technology entrepreneurs' mix of conservative views on regulation and liberal views on economic redistribution is unique. Figure [5 shows that there is a nearly perfect correlation between how economically conservative each sample is on matters of regulation and how economically conservative it is on matters of redistribution-except for technology entrepreneurs. This pattern is consistent with our broader theoretical argument that economic elites in an industry may share a highly distinctive set of policy views; no other samples evince technology entrepreneurs' mix of liberal redistributive but conservative regulatory views.

To confirm that technology entrepreneurs indeed tend to support redistribution yet oppose

\footnotetext{
${ }^{26}$ See Online Appendix F
} 
Figure 5: Technology Entrepreneurs' Distinctive Set of Economic Views

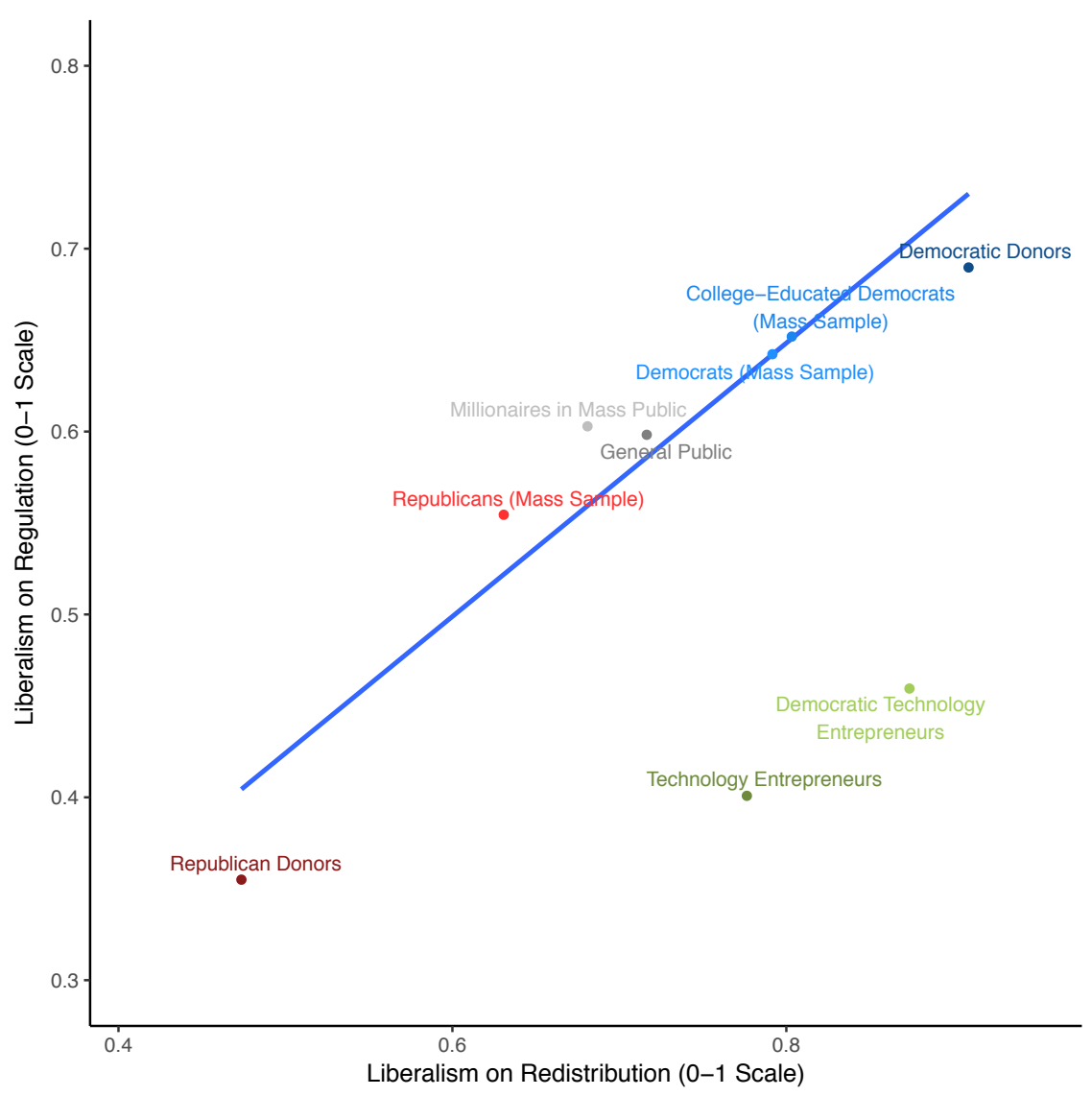

Notes: Each point shows the mean of each sample's scores on the redistribution and regulation scales on the $x$ and $y$ axes, respectively. The blue line shows the line of best fit for samples other than the technology sample.

regulation more than other Democrats, we also asked our samples to indicate which of four statements came closest to their views, with response options such as "The government should tightly regulate business, and should tax the wealthy to fund social programs," "The government should not tightly regulate business, and should tax the wealthy to fund social programs," and so on. Table 3 shows the results. Technology entrepreneurs are the only group to predominantly select the option "The government should not tightly regulate business, and should tax the wealthy to fund social programs," with a majority selecting this option-nearly twice as many as any other group, including millionaires in the mass public and the current donor base of both 
parties.

Table 3: Technology Entrepreneurs Uniquely Support Redistribution but Oppose Regulation

\begin{tabular}{|c|c|c|c|c|c|c|}
\hline & $\begin{array}{c}\text { Technology } \\
\text { Entrepreneurs }\end{array}$ & $\begin{array}{l}\text { Democratic } \\
\text { Donors }\end{array}$ & $\begin{array}{l}\text { Republican } \\
\text { Donors }\end{array}$ & $\begin{array}{l}\text { Democrats } \\
\text { (Public) }\end{array}$ & $\begin{array}{l}\text { Republicans } \\
\text { (Public) }\end{array}$ & $\begin{array}{l}\text { Millionaires } \\
\text { (Public) }\end{array}$ \\
\hline $\begin{array}{l}\text { Do Regulate and } \\
\text { Do Redistribute }\end{array}$ & $17.9 \%$ & $62.6 \%$ & $2.8 \%$ & $53.8 \%$ & $28.8 \%$ & $31.8 \%$ \\
\hline $\begin{array}{l}\text { Don't Regulate and } \\
\text { Do Redistribute }\end{array}$ & $60.1 \%$ & $34.7 \%$ & $20.9 \%$ & $36.3 \%$ & $34.5 \%$ & $30.3 \%$ \\
\hline $\begin{array}{l}\text { Do Regulate and } \\
\text { Don't Redistribute }\end{array}$ & $2.8 \%$ & $1.2 \%$ & $1.6 \%$ & $6.0 \%$ & $9.3 \%$ & $9.1 \%$ \\
\hline $\begin{array}{l}\text { Don't Regulate and } \\
\text { Don't Redistribute }\end{array}$ & $19.3 \%$ & $1.5 \%$ & $74.7 \%$ & $3.9 \%$ & $27.4 \%$ & $28.8 \%$ \\
\hline
\end{tabular}

In summary, we have shown that a majority of technology entrepreneurs have a pattern of views that is rare among other groups of wealthy individuals or in the public: a mix of liberal views on issues related to social, global, and economic redistribution, but conservative views in the economic domain on matters of regulation.

\section{Results Consistent with Theoretical Mechanisms}

In this section we present data that is consistent with the theoretical mechanisms we posited for why economic elites who made their money in a particular industry such as technology would share a particular pattern of views: the particular set of predispositions that those in an industry would tend to share as a result of who selects into each industry, who succeeds in it, and the experiences they have working in it. In the case of technology entrepreneurs, as described previously, we anticipated that their views on social issues would arise in part from low authoritarianism, that their globalist views would arise in part from their high cosmopolitanism, that their support for redistribution would arise in part from their low racial resentment, and that their hostility to regulation would arise in part from their positive attitudes towards markets and entrepreneurs. This helps address the puzzle of why technology entrepreneurs have conservative views on regulation despite their 
liberal views on other issues—including other economic issues.

To test whether differences in these predispositions help explain the distinctive pattern of policy views technology entrepreneurs hold, we conduct a wide array of tests. Each of these tests has complementary strengths and weaknesses; they together help build support for multiple empirical predictions of our theoretical argument.

\section{Documenting Differences in Predispositions}

First, we document differences in measures of the four predispositions we previously specified. This establishes the plausibility of our argument that differences in predispositions help explain the particular set of views technology entrepreneurs share. Table 4 summarizes the items we used to measure each of these predispositions. Online Appendix 『contains the full item wordings.

Table 4: Summary of Survey Items in Each Predisposition Scale

\begin{tabular}{|c|c|}
\hline Authoritarianism & Cosmopolitanism \\
\hline $\begin{array}{l}\text { Source: Feldman and Stenner }(1997) \\
\text { child rearing questions. } \\
\text { - Obedience or Self-Reliance } \\
\text { - Curiosity or Good Manners } \\
\text { - Being Considerate or Well Behaved } \\
\text { - Independence or Respect for Elders }\end{array}$ & $\begin{array}{l}\text { Source: Jackman and Vavreck }(2011) \\
\text { - Consider self citizen of world. } \\
\text { - Hold a passport. } \\
\text { - Been to Canada or Mexico. } \\
\text { - Been to Europe. } \\
\text { - Been to Africa, Asia, or South America. } \\
\text { - Gone to an Indian restaurant. } \\
\text { - Eaten sushi. }\end{array}$ \\
\hline $\begin{array}{l}\text { Racial Resentment } \\
\text { Source: Kinder and Sanders (1996), } \\
\text { abbreviated. } \\
\text { - If blacks only tried harder, they would be } \\
\text { better off. } \\
\text { - Blacks have gotten less than they deserve. }\end{array}$ & $\begin{array}{l}\text { Markets and Entrepreneurs } \\
\text { Here we summarize this disposition } \\
\text { with a question about the contribution } \\
\text { of entrepreneurs to the economy. } \\
\text { See next section for survey experiments } \\
\text { using additional measures of positive } \\
\text { predispositions towards markets and } \\
\text { entrepreneurs that operate even in } \\
\text { policy domains beyond their self-interest. }\end{array}$ \\
\hline
\end{tabular}


To confirm our premise that there is a relationship between each of the policy areas and the corresponding predisposition we measured, in Online Appendix Table OA5 we replicate the bivariate relationships other research has found between these values and predispositions and these policy areas in our mass public sample (all relationships significant at $p<0.01$ ). For instance, moving across the range of authoritarianism is associated with a 0.82 standard deviation change in attitudes on social attitudes.

We next present several tests of our predictions regarding the theoretical mechanisms underlying technology entrepreneurs' distinctive pattern of policy views. As a first test, we predicted that technology entrepreneurs would have very liberal underlying values and predispositions in the areas we hypothesized would correspond with their liberal views. Figure 6 shows that the results confirm this prediction. Technology entrepreneurs are very low in authoritarianism, very high on cosmopolitanism, and very low on racial resentment.

\section{Why Do Technology Entrepreneurs Oppose Regulation?}

The next body of evidence we present with regard to theoretical mechanisms is focused on explaining our most surprising result: that technology entrepreneurs are conservative on issues of government regulation despite their liberalism on other economic and non-economic issues.

\section{Ruling out Demographics and Geography}

To triangulate the mechanism responsible, we first test implications of two obvious alternative explanations for technology entrepreneurs' opposition to regulation: a simple demographic explanation and geography. We find no evidence for either.

Due to space constraints, we present these results in Online Appendix C.4 and only briefly review them here. First, using the mass public sample, we find it is not the case that wealthy or highly educated individuals or Democrats are generally hostile to regulation; something is different about technology entrepreneurs. Even millionaires in the mass public are more friendly 
Figure 6: Values and Predispositions

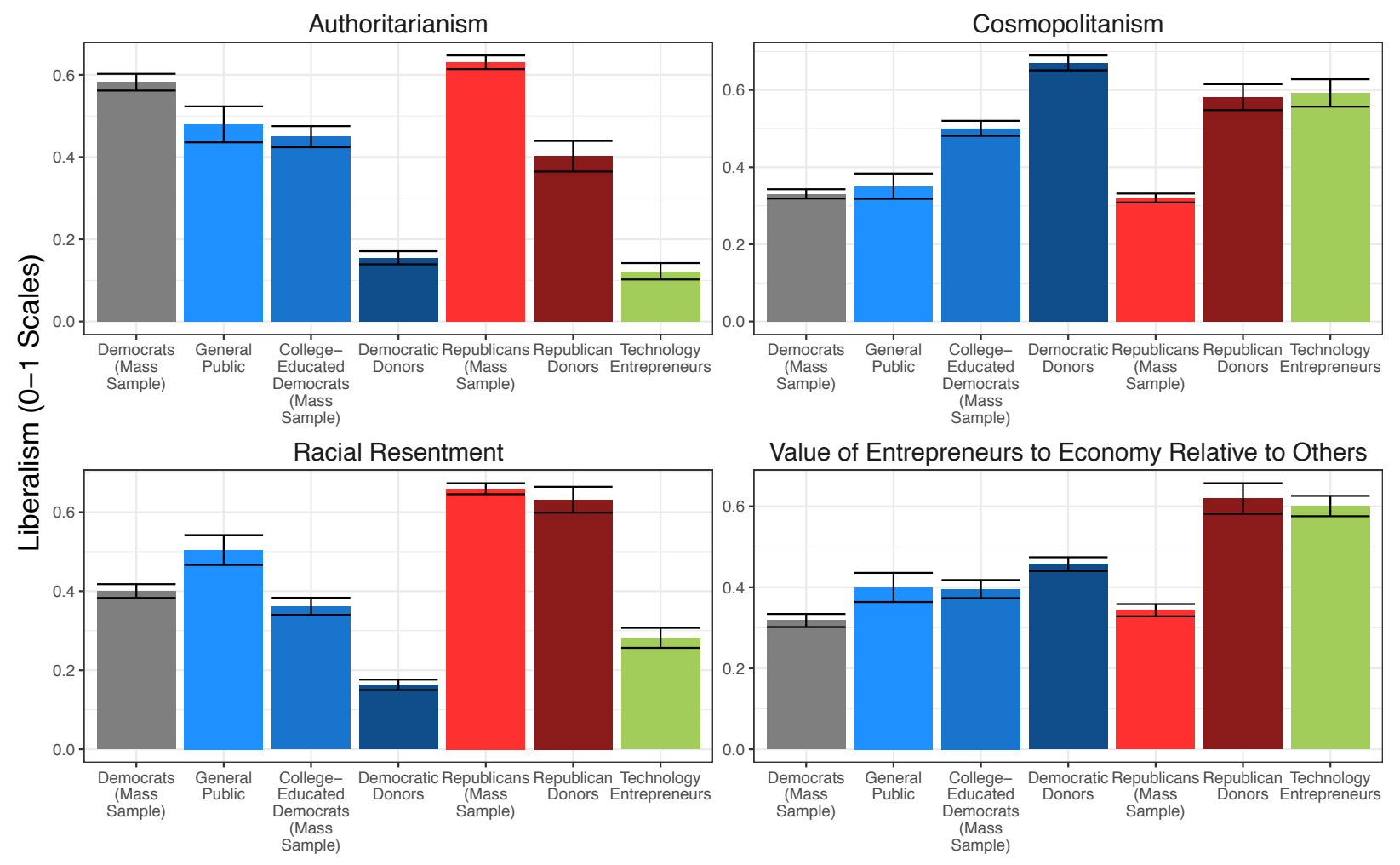

to regulation than technology entrepreneurs. We also present regressions that control for education, gender, age, and income and still find the same differences between our samples even conditional on these traits. Finally, we show that the unique pattern of views held by economic elites from the technology industry also does not appear attributable to where they tend to live, as the results are the same when we conduct our comparisons within geographic areas.

\section{Opposition to Regulation of Non-Technology Companies}

Another possible explanation for technology entrepreneurs' opposition to regulation is that they are answering with the technology industry's economic interests in mind. Our argument allows for economic interests to affect technology entrepreneurs' views, but holds that predispositions exert their own influence in addition. We conducted three analyses to test whether technology 
entrepreneurs' hostility to regulation manifests over and above self-interested concerns by examining their views towards both technology and non-technology products and services.

Uber versus Florists Survey Experiment. We first test whether technology entrepreneurs still take entrepreneurs' side of a contentious issue when the same underlying principle is at play but we vary whether the entrepreneurs are from the technology industry or not. In particular, one salient example of a growing technology company that has faced the threat of regulation is Uber; specifically, its practice of "surge pricing," or raising fares at times of high demand. Unsurprisingly, when we asked technology entrepreneurs whether they thought Uber's surge pricing was fair, 93\% said that they did. On the other hand, both Democrats and Republicans in the mass public were split, with only $43 \%$ and $51 \%$ respectively finding it fair (differences from technology entrepreneurs significant at $p<0.01$ ).

A between-subjects survey experiment we conducted suggests that technology entrepreneurs' support for demand-based pricing reflects their broader principles and not only a defense of a technology company. Half of each sample did not see a question about Uber's surge pricing but instead a question from Shiller, Boycko and Korobov (1990) touching on the same underlying principle in a different industry: "On a holiday, when there is a great demand for flowers, sellers usually increase their prices. Do you think it is fair for them to raise their prices like this?" Figure 7 shows that technology entrepreneurs were just as likely to consider this practice fair (96\%), even though it has nothing to do with the technology industry. But a majority of both Democratic and Republican partisans, $61 \%$ and 58\% respectively, still considered it unfair (differences with technology entrepreneurs significant at $p<0.01$ ). This contrast suggests an underlying difference in how technology entrepreneurs view markets, regardless of whether their own industry is implicated.

Regulation of business question wording experiment. We conducted a second survey experiment in a similar spirit that probed individuals' attitudes about regulation more explicitly. In our survey, we modified the standard agree-disagree survey question, "Government regulation 
Figure 7: Uber versus Florists Survey Experiment

Uber surge pricing fair.
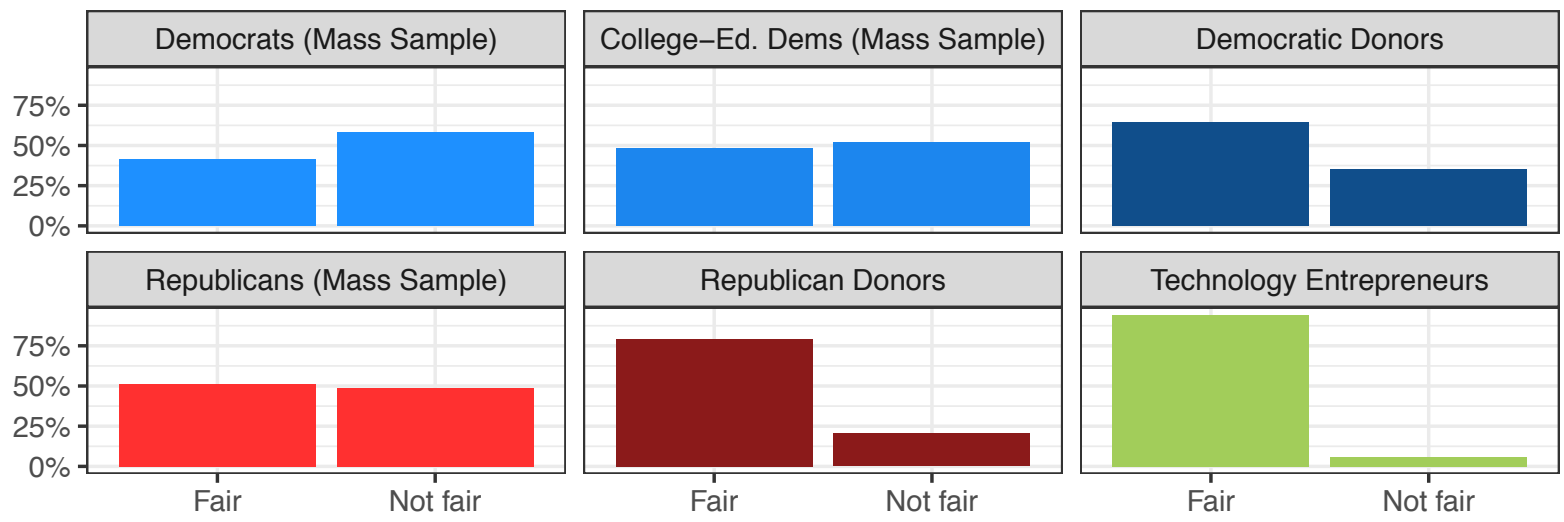

Florists raising prices on holidays fair.
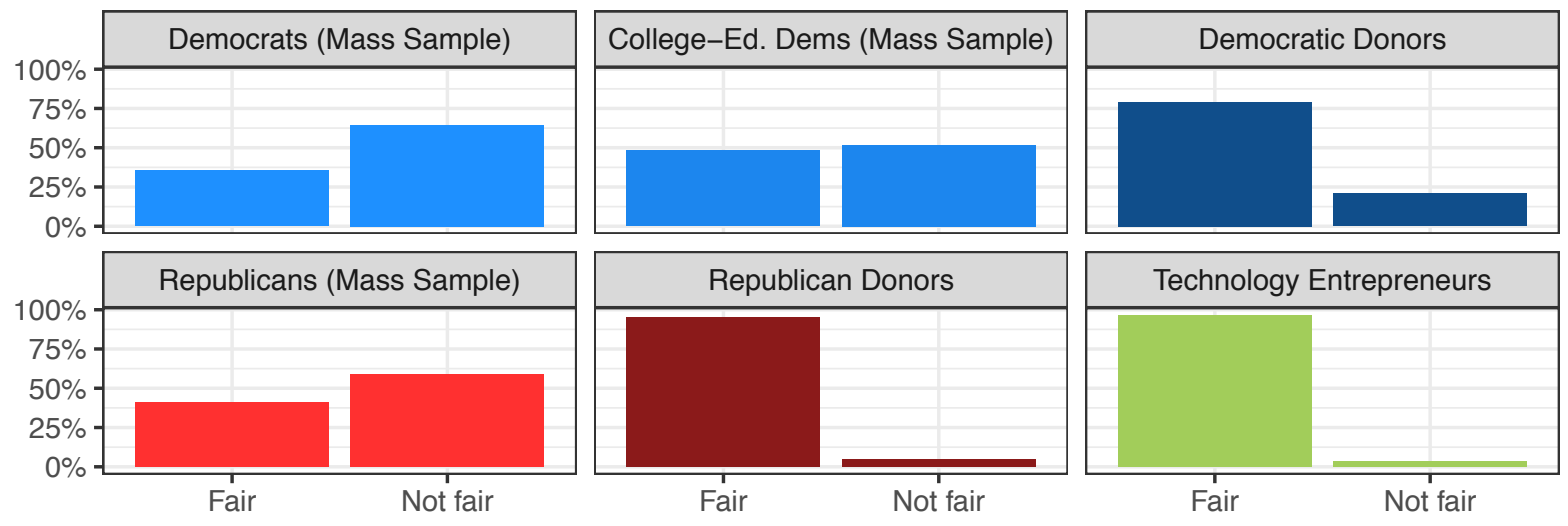

of business does more harm than good," to see whether technology entrepreneurs would be especially likely to agree if we changed the question to focus on the technology industry specifically (e.g., "Government regulation of the technology industry does more harm than good.”).

The results do not support the view that technology entrepreneurs answer questions about regulation differently than other groups only because they are more likely to be looking out for the technology industry's interests. Table 5 shows their agreement increases by 0.3 scale points to 2.7 when the technology industry is the focus on the question. However, other Democrats without 
Table 5: Technology Entrepreneurs More Likely to Oppose Regulation of Technology, Less Likely to Oppose of Other Industries; But So Are Other Democrats

\begin{tabular}{|c|c|c|c|c|}
\hline & \multicolumn{4}{|c|}{$\begin{array}{c}\text { DV = "Government regulation of [CATEGORY] } \\
\text { does more harm than good." (1-4 scale) }\end{array}$} \\
\hline & $\begin{array}{c}\text { Technology } \\
\text { Entrepreneurs }\end{array}$ & $\begin{array}{l}\text { Democratic } \\
\text { Donors }\end{array}$ & $\begin{array}{l}\text { Democratic } \\
\text { Partisans }\end{array}$ & $\begin{array}{l}\text { All Three } \\
\text { Groups }\end{array}$ \\
\hline Treatments & & & & \\
\hline "the technology industry" & $\begin{array}{l}0.28^{*} \\
(0.11)\end{array}$ & $\begin{array}{c}0.46 * * * \\
(0.07)\end{array}$ & $\begin{array}{l}0.19 * \\
(0.09)\end{array}$ & $\begin{array}{l}0.28 * \\
(0.11)\end{array}$ \\
\hline "the financial industry & $-0.50 * * *$ & $-0.32 * * *$ & $-0.20^{*}$ & $-0.50 * * *$ \\
\hline (such as banks)" & $(0.11)$ & $(0.08)$ & $(0.09)$ & $(0.12)$ \\
\hline "the pharmaceutical industry" & $\begin{array}{c}-0.37 * * \\
(0.11)\end{array}$ & $\begin{array}{l}-0.08 \\
(0.07)\end{array}$ & $\begin{array}{l}-0.10 \\
(0.08)\end{array}$ & $\begin{array}{c}-0.37^{* *} \\
(0.11)\end{array}$ \\
\hline \multicolumn{5}{|l|}{ Sample Dummies (Technology } \\
\hline Democratic Donors & & & & $\begin{array}{c}-0.94 * * * \\
(0.10)\end{array}$ \\
\hline Democrats (Mass Public) & & & & $\begin{array}{l}-0.03 \\
(0.10)\end{array}$ \\
\hline \multicolumn{5}{|l|}{ Treatment X Sample Interactions } \\
\hline Technology x Democratic Donors & & & & $\begin{array}{l}0.18 \\
(0.14)\end{array}$ \\
\hline Technology x Democrats (Mass Public) & & & & $\begin{array}{l}-0.09 \\
(0.14)\end{array}$ \\
\hline Finance $\mathrm{x}$ Democratic Donors & & & & $\begin{array}{c}0.19 \\
(0.14)\end{array}$ \\
\hline Finance x Democrats (Mass Public) & & & & $\begin{array}{l}0.30^{*} \\
(0.14)\end{array}$ \\
\hline Pharmaceuticals x Democratic Donors & & & & $\begin{array}{l}0.29 * \\
(0.14)\end{array}$ \\
\hline Pharmaceuticals x Democrats (Mass Public) & & & & $\begin{array}{c}0.27 \\
(0.14)\end{array}$ \\
\hline $\begin{array}{l}\text { Constant (Base Category = Tech. } \\
\text { Entrepreneurs' Responses } \\
\text { When No Industry Is Specified) }\end{array}$ & $\begin{array}{c}2.61 * * * \\
(0.08)\end{array}$ & $\begin{array}{c}1.67 * * * \\
(0.05)\end{array}$ & $\begin{array}{c}2.58^{* * * *} \\
(0.06)\end{array}$ & $\begin{array}{c}2.61^{* * * *} \\
(0.08)\end{array}$ \\
\hline Observations & 439 & 846 & 817 & 2,102 \\
\hline R-squared & 0.13 & 0.12 & 0.02 & 0.25 \\
\hline
\end{tabular}


a stake in regulation of the technology industry react similarly to this manipulation. In fact, Democratic donors react even more strongly to the "technology industry" treatment than the technology entrepreneurs, suggesting that there is a more general view among Americans that regulation of the technology industry is slightly more harmful than regulation of other industries, and that technology entrepreneurs are not dissimilar in holding this view. As the bolded coefficients in the final column of Table 5 show, the technology entrepreneurs' reaction to the treatment that focused on technology regulation is statistically indistinguishable from that of other Democrats.

Views toward Regulating Technology Versus Non-Technology Industries. As a final test, we also investigated whether technology entrepreneurs would remain more opposed to regulation than Democratic citizens and donors when we asked about non-technology products and services, and compared how these differences between groups would vary when technology products and services were the focus. ${ }^{27}$ Our surveys asked respondents "Do you think government regulation of business should increase, stay the same, or decrease in the following areas?" We asked about three technology industries (drones, self-driving cars, Internet data) and three non-technology industries (finance, health insurance, oil/gas). We stacked the data at the respondent-by-industry level and then estimated an OLS regression model predicting anti-regulation attitudes (on the three-point response scale recoded to range from 0 to 1) with a dummy representing technology elites, a dummy representing whether the industry in question was technology related, and the interaction between the two.

We find that technology entrepreneurs are more opposed to regulation than Democrats regardless of the industry in question. The first coefficient in Table 6 for the main effect of technology elites shows that technology elites are on average 0.083 scale points more opposed to regulation of non-technology industries than the Democratic samples $(p<0.01)$. The second coefficient for the main effect of technology products and services shows that the Democratic

\footnotetext{
${ }^{27}$ This analysis was not pre-registered; we conceived it on the basis of a comment from a peer reviewer.
} 
samples are on average 0.053 more opposed to regulation of technology products and services than the non-technology products and services $(p<0.01)$. The final, statistically insignificant and substantively small coefficient on the interaction term of 0.012 indicates that technology entrepreneurs are similar to other Democratic samples in their reaction to regulation of technology versus non-technology companies.

Table 6: Technology Entrepreneurs No More Likely to Oppose Regulating Technology Products than Democratic Groups

\begin{tabular}{lc}
\hline & $\begin{array}{c}\text { DV = Opposition to regulation of particular } \\
\text { products and services }(0-1 \text { scale })\end{array}$ \\
\hline Technology Elites & $0.083^{* *}$ \\
& $(0.014)$ \\
Tech Product/Service & $0.053^{* *}$ \\
& $(0.006)$ \\
Technology Elites x Tech Product/Service & 0.012 \\
& $(0.016)$ \\
Constant (Base Category & $0.200^{* *}$ \\
Democratic Samples) & $(0.006)$ \\
& \\
Observations & 12,656 \\
R-squared & 0.018 \\
\hline Robust standard errors clustered by respondent in parentheses & \\
$* * \mathrm{p}<0.01, * \mathrm{p}<0.05$ (two-tailed). &
\end{tabular}

Notes: Data is stacked at the respondent-by-product/service level. Only technology elites, Democratic donors, and Democratic partisans in the public are included in this regression.

To summarize, the three analyses in this subsection consistently find that technology entrepreneurs are more opposed to regulation than Democrats regardless of whether the technology industry's interests are at stake. This consistent pattern suggests that technology entrepreneurs have a favorable disposition in favor of entrepreneurs and against government regulation that transcends the interests of the technology industry. 


\section{Other Attitudes Consistent with Hypothesized Predispositions}

To further test our theoretical argument that economic elites from an industry may share distinct political predispositions, we next conduct additional tests of our empirical prediction that-despite their liberal views on economic redistribution-technology entrepreneurs react especially positively towards markets and entrepreneurs and more negatively towards government intervention in the economy.

Privately versus Publicly Administered Services. First, technology entrepreneurs' greater friendliness towards market (vs. government-based) solutions extends to their views over how redistribution should take place. Column 1 of Table 7 reports a regression with the outcome computed as the difference between support for government-run programs and private-sector run programs on indicators for each group. The baseline category is technology entrepreneurs, meaning the constant term shows they are 0.39 scale points more in favor of programs run by the private sector rather than government. This is essentially identical to Republicans citizens and significantly different from Democratic donors $(p<0.01)$ and citizens $(p<0.01)$, who are more supportive of having the government run publicly funded programs.

Belief That Government Programs Do a Good Job. We next asked respondents whether they thought "the government generally does a good job of running social programs meant to help poor people." The second column of Table 7 shows that technology entrepreneurs were more likely to disagree than agree with this question. Democrats were much more likely to agree.

Positive Views of Entrepreneurs. They also have a highly positive view of entrepreneurs, as first previewed in Figure 6. The third column of Table 7 shows a regression with the outcome of whether individuals agreed with the statement that "Entrepreneurs and other people with new ideas get too much credit these days; ordinary people who work hard are the backbone of this country." Technology entrepreneurs are similar to Republican donors on this question, and distinct from all Democratic groups.

Opposition to both private and public sector union influence. We also asked technology 
Table 7: Relative to Democrats, Technology Entrepreneurs Prefer Private- to Public-Sector Management Generally

\begin{tabular}{lccc}
\hline & $\begin{array}{c}\text { Approval of Privately } \\
\text { Run Programs (1-5) } \\
\text { Minus Approval of } \\
\text { Gov't Run Social } \\
\text { Programs (1-5) }\end{array}$ & $\begin{array}{c}\text { Gov't Does Good } \\
\text { Job Running } \\
\text { Social Programs }\end{array}$ & $\begin{array}{c}\text { Entrepreneurs } \\
\text { Get Too Much } \\
\text { Credit (1-4) }\end{array}$ \\
\hline \multirow{2}{*}{ Democratic Donors } & $-1.73 * * *$ & \\
& $(0.10)$ & $0.64 * * *$ & $0.43 * * *$ \\
Democrats (Mass Public) & $-0.62^{* * *}$ & $(0.05)$ & $(0.05)$ \\
& $(0.10)$ & $0.17 * * *$ & $0.76^{* * *}$ \\
Republican Donors & $1.16^{* * *}$ & $(0.05)$ & $(0.05)$ \\
& $(0.13)$ & $-0.89 * * *$ & -0.06 \\
Republicans (Mass Public) & -0.05 & $(0.07)$ & $(0.06)$ \\
& $(0.10)$ & $-0.15 * *$ & $0.76^{* * *}$ \\
Constant (Base Category $=$ & $0.44 * * *$ & $(0.05)$ & $(0.05)$ \\
Technology Entrepreneurs) & $(0.08)$ & $2.19 * * *$ & $2.20 * * *$ \\
& & $(0.04)$ & $(0.04)$ \\
Observations & 2,952 & 2,940 & 3,069 \\
R-squared & 0.22 & 0.21 & 0.13 \\
\hline
\end{tabular}

Standard errors in parentheses.

$* * * \mathrm{p}<0.001, * * \mathrm{p}<0.01, * \mathrm{p}<0.05$ (two-tailed).

entrepreneurs whether they would like to see labor unions' influence decline, but randomly assigned whether we asked them about public sector or private sector unions. We would expect technology entrepreneurs to oppose both private and public sector unions because unions constrain the ability of managers to freely hire and fire workers. Significantly, although technology entrepreneurs have weaker economic interests in opposing influence from public sector than private sector unions, they are just as likely to say they would like see private sector (76\%) and public sector (72\%) unions influence decline (see Online Appendix Figure OA3).

These questions and experiments support our prediction that technology entrepreneurs hold genuine values and predispositions related to free markets and government involvement in the economy that lead them to differ strongly from Democrats on regulation, even when the technology industry's interests are not at stake ${ }^{28}$ In Online Appendix $\mathrm{H}$, we show that these relationships and differences with other Democrats hold even when examining technology entrepreneurs who

\footnotetext{
${ }^{28}$ As expected, relationships between the three variables we used as outcomes in Table 7 correlate with opposition to regulation more generally. We report these relationships in Table OA6.
} 
identify as Democrats. Again, technology entrepreneurs hold these conservative economic values relevant to regulation despite being very liberal on economic redistribution.

\section{Comparison to Undergraduate Computer Science and Biology Majors}

Our theory argues that economic elites from particular industries will tend to share unique sets of policy attitudes in part due to the pre-existing predispositions that lead individuals to select into working in each industry in the first place. To test this mechanism, we examine whether college students who have shown an interest in the technology industry will exhibit many of the predispositions and policy views that also characterize older wealthy technology entrepreneurs. Examining college students also allows us to capture attitudes before these individuals have immediate economic interests, although of course undergraduates may be forward looking. ${ }^{29}$

To test this prediction of our argument, we surveyed computer science majors at Stanford University, which graduates the most technology company founders of any US university. ${ }^{30}$ We also surveyed biology majors from the same institution as a comparison group to show that the patterns we find among computer science majors are not present generally among STEM undergraduates at this institution 31

Figure 8 displays our four policy preference indices among college-educated Democrats, Democratic donors, technology entrepreneurs, and our two undergraduate samples ${ }^{32}$ Computer science and biology majors at this university are both more liberal than other college-educated Democrats in the mass public on every issue-with the exception that computer science majors in particular, to a greater extent than biology majors, are notably less liberal than the public on the

\footnotetext{
${ }^{29}$ For other research that surveys undergraduates to understand processes of political socialization, see Lawless and Fox (2015).

30"These schools graduate the most funded startup CEOs", TechCrunch, https: / / echcrunch.com/2018/ 05/12/these-schools-graduate-the-most-funded-startup-ceos/

${ }^{31}$ Online Appendix Section E.4 describes the survey procedures. Our undergraduate survey instrument was identical to our other surveys. Undergraduates at this university can declare either major as early in their undergraduate careers as they like, and there are no requirements (e.g., course prerequisites) for declaring either major.

${ }^{32}$ Online Appendix Table $\mathrm{OA} 1$ presents equivalent regressions.
} 
issue of regulation. This is the same pattern as we see with adult technology entrepreneurs, exactly as our theory would predict.

Likewise, Online Appendix Table OA2 shows that computer science majors are similar to technology entrepreneurs in being especially likely to select the "Don't Regulate and Do Redistribute" option on the four-option question about regulation and redistribution we had previously shown in Table 3. A majority of computer science majors selected this option-57\% - a figure indistinguishable from the technology sample. This is the only other sample we studied where a majority selected this option. A much smaller share of biology undergraduates did so-39\% - a figure significantly different than the computer science majors and technology entrepreneurs ( $p<0.01$ for both comparisons).

Figure 8: Comparing Democrats, Technology Entrepreneurs, and Undergraduates - Policy Views
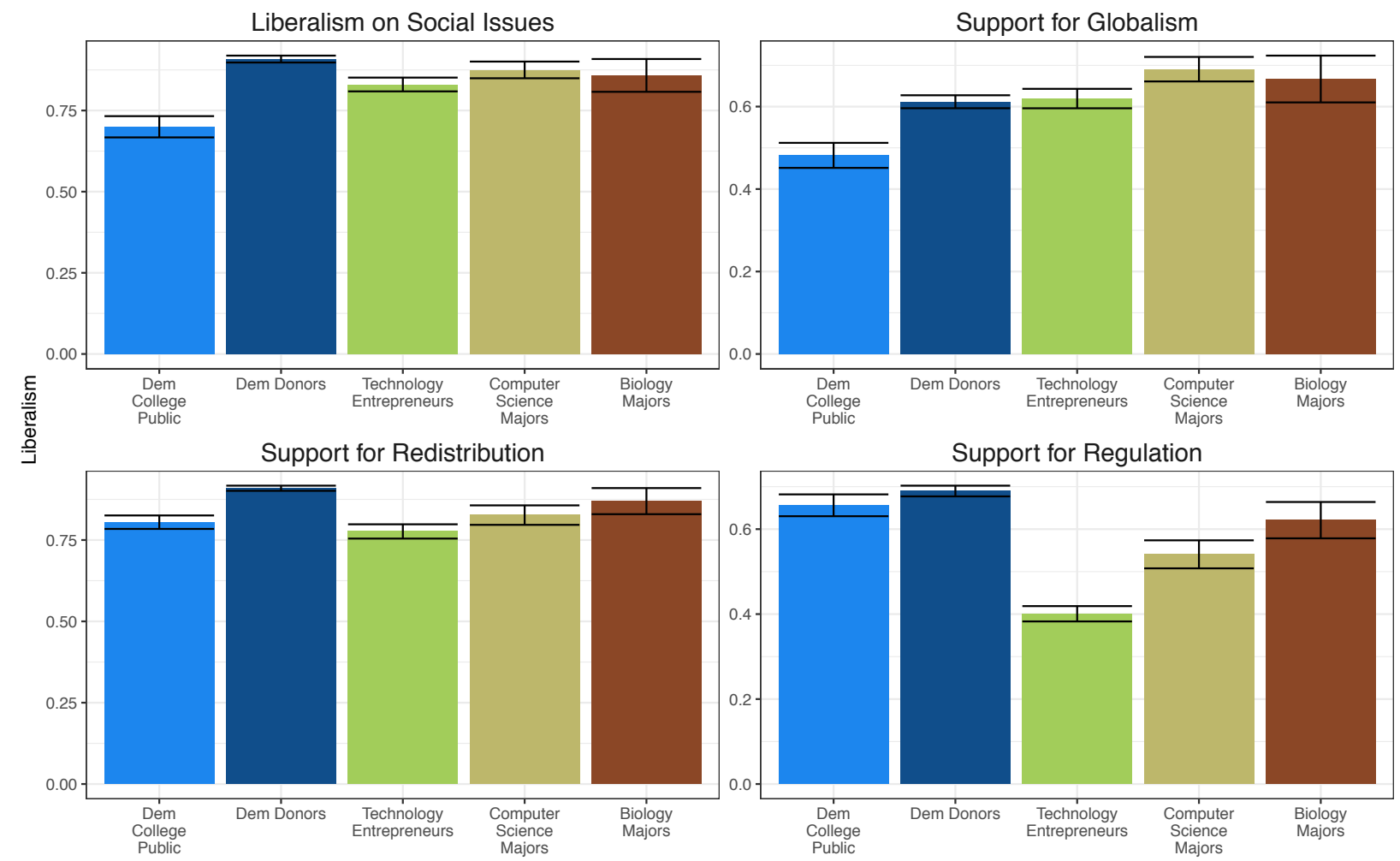

Online Appendix E.4.1 presents additional results on specific items. These results are broadly consistent with computer science undergraduates resembling technology elites more on matters 
of underlying principle and less for issues where economic interests or experience working in the industry is likely to color individuals' views. For example, on issues like whether it is fair for entrepreneurs to raise prices-be they florists or a technology company like Uber-the computer science majors are indistinguishable from technology entrepreneurs and quite distinct from both biology majors and other Democratic groups. But, when it comes to labor unions-an issue on which we would not expect undergraduates to have much direct experience-computer science majors look like other Democrats.

In summary, our survey of undergraduates provides additional support for our theory that individuals entering certain industries will share particular predispositions and longstanding attitudes. Undergraduate computer science majors already exhibit many of the distinctive patterns of views and predispositions present among technology entrepreneurs-patterns that their peers majoring in biology did not exhibit.

As with our other evidence, our survey of undergraduates does not definitively rule out all other alternative explanations ${ }^{33}$ However, this evidence joins the other evidence we presented above that, as a whole, validates many predictions of our theory about the relevance of predispositions to economic elite's political views.

\section{Discussion}

In a time of rising economic inequality, one of the most theoretically influential and publicly relevant areas of political science research concerns how economic elites influence politics. Research establishes that economic elites can potentially exert outsized influence, but we know surprisingly little about what economic elites want government to do and why. In this paper, we drew on theories of mass political behavior to argue that economic elites from particular

\footnotetext{
${ }^{33}$ For example, it remains possible that computer science majors are internalizing their future self-interest (although this would not explain why they support taxing the wealthy given that a large share of them, statistically, are likely to become wealthy). Nor would it explain why they, like the technology entrepreneurs, support the price discrimination practices of florists.
} 
industries may share distinctive values and predispositions that lead them to support a distinctive set of policies. Those in a given industry, we argued, might share a distinctive pattern of predispositions due to the unique kind of individuals that select into working in each industry, succeed in it, and the experiences they have within it. The implication of our argument is that we should not expect a simple, positive relationship between increases in economic elites' political influence and the enactment of policies that exacerbate inequality. Instead, we expect the impact of any growth in economic elite's influence on politics and inequality to depend on which industry's rich are getting more influential and which policy area is at stake.

In the United States, for example, many new millionaires and billionaires made their money in the technology industry. Our argument holds that it should matter that so many new economic elites are from this industry because a particular kind of individual may be attracted to becoming a technology entrepreneur. To demonstrate this argument, we conducted the two largest surveys of American economic elites to date. These unique surveys allowed us to test key predictions of our broader argument. Our findings were by no means obvious. We showed that technology entrepreneurs are different than economic elites in general. Moreover, they are not simply libertarians (economic conservatives and social liberals), nor simply liberals or conservatives. Indeed, very few of them fit any of these traditional categories. Rather, they share a unique set of predispositions that correspond with liberal policy preferences in many domains, including taxation and government spending — but not on government regulation. Using our other surveys to provide points of comparison, we established that this pattern of views is unique to technology entrepreneurs, not being seen in other groups of wealthy individuals, including among the Democratic Party's current donor base or among millionaires in the mass public. Technology entrepreneurs were more conservative than these groups in the regulatory domain despite being more liberal than them in other domains. Additional evidence consistent with our argument also helped illuminate why technology entrepreneurs have distinctive views in the domain of regulation. We showed that beyond industry incentives, their positive predispositions towards 
markets and entrepreneurs appear to be why their views differ from other Democrats, differences that emerged even when comparing Democratic citizens and donors to the technology entrepreneurs who explicitly identify as Democrats. Finally, in a comparison with undergraduate biology and computer science majors, we found that many of these differences between technology entrepreneurs and other educated individuals in scientific fields appear to manifest even before they enter the workforce-consistent with longstanding predispositions playing a role.

On a substantive level, the differences we found between technology entrepreneurs and other Democratic groups portend changes within the Democratic Party with mixed implications for inequality. On the one hand, technology entrepreneurs seem poised to support Democratic candidates-and therefore redistributive policies that should reduce inequality-financially; campaign contributions by the Forbes 400 have trended Democratic in recent years largely because of the growing presence of wealthy technology entrepreneurs in this elite group (Bonica and Rosenthal 2015). But this will also likely secure technology entrepreneurs influence with Democratic officeholders. Indeed, Figure 2 showed that Democratic donors expect that technology entrepreneurs are likely to gain influence within the Democratic Party in the coming years, coupled with a declining influence of organized labor. And despite their liberal views in many domains, these technology entrepreneurs generally stand opposed to many government interventions in markets-such as government support for labor unions, worker protections, and consumer protections - that have long been central to the Democratic Party's ideological answer to inequality and supported by traditional Democratic constituencies such as unions. As Democratic elected officials receive increasing financial support from technology entrepreneurs and attempt to court further support from them still, struggles over the position of the Democratic Party on regulating product and labor markets thus may take center stage.

Changes in the American economy are also affecting the balance of economic power across other industries. What do our theory and data indicate about economic elites in these industries? 
No representative surveys of economic elites exist as far as we know, and the little data on economic elites that does exist is too limited at present to test further implications of our theory for other industries. We were able to show that technology entrepreneurs are different than other economic elites generally, such as millionaires in the mass public and wealthy partisan donors. For example, Online Appendix $\mathrm{F}$ showed that technology entrepreneurs are more opposed to regulation than other millionaires but also more liberal on other issues than other millionaires. Nevertheless, although ours is the first study of its kind on any industry, we hope that our work will open up a research agenda that examines such variation across industries ${ }^{34}$

In addition, as with all descriptive work, one limitation of this research is that we cannot definitively establish the causal dynamics of the relationships we demonstrated. Although the underlying political behavior theories we drew from have been carefully tested elsewhere (e.g., Tesler 2015), we would welcome future research that more firmly establishes the causal relationships and mechanisms underpinning the relationships we demonstrated.

We should also stress that our argument is not that the predispositions common in an economic elite's industry are all that matters for their politics. Future work can and should explore how economic elites navigate conflicts between their industry's interests and their own predispositions. What we have established is that analyses of the interplay between economic inequality and political power should pay greater attention to the predispositions held by the particular group of economically elite individuals whose wealth and political power are growing.

\section{References}

Bartels, Larry M. 2008. Unequal Democracy. Princeton, NJ: Princeton University Press.

Bawn, Kathleen, Martin Cohen, David Karol, Seth Masket, Hans Noel and John Zaller. 2012. "A

\footnotetext{
${ }^{34}$ The individuals in each industry who opt into donating to each party are also not random, meaning it is unclear what variation we would expect by occupation within our donor survey. Our mass public sample, like most, also has too few wealthy individuals to provide meaningful data.
} 
Theory of Political Parties: Groups, Policy Demands and Nominations in American Politics." Perspectives on Politics 10(3):571-597.

Berinsky, Adam J. 2017. "Measuring Public Opinion with Surveys.” Annual Review of Political Science 20:309-329.

Bonica, Adam and Howard Rosenthal. 2015. "The Wealth Elasticity of Political Contributions by the Forbes 400." Working Paper, Available at https: / / ssrn . com/abstract=2668780.

Dahl, Robert A. 1961. Who Governs? New Haven, CT: Yale University Press.

Enns, Peter K. 2015. “Relative Policy Support and Coincidental Representation.” Perspectives on Politics 13(4):1053-1064.

Feddersen, Timothy, Sean Gailmard and Alvaro Sandroni. 2009. "Moral Bias in Large Elections: Theory and Experimental Evidence.” American Political Science Review 103(2):175-192.

Feldman, Stanley and Karen Stenner. 1997. "Perceived Threat and Authoritarianism." Political Psychology 18(4):741-770.

Gerber, Alan S., Gregory A. Huber, David Doherty, Conor M. Dowling and Shang E. Ha. 2010. "Personality and Political Attitudes: Relationships Across Issue Domains and Political Contexts." American Political Science Review 104(1):111-133.

Gilens, Martin. 1999. Why Americans Hate Welfare. Chicago: University of Chicago Press.

Gilens, Martin and Benjamin I. Page. 2014. "Testing Theories of American Politics: Elites, Interest Groups, and Average Citizens.” Perspectives on Politics 12(3):564-581.

Hacker, Jacob S and Paul Pierson. 2017. American Amnesia. New York: Simon and Schuster.

Hertel-Fernandez, Alexander. 2018. Politics at Work. New York: Oxford University Press. 
Hetherington, Marc J. and Jonathan D. Weiler. 2009. Authoritarianism and Polarization in American Politics. New York: Cambridge.

Jackman, Simon and Lynn Vavreck. 2011. Cosmopolitanism. In Facing the Challenge of Democracy: Explorations in the Analysis of Public Opinion and Political Participation, ed. Paul M. Sniderman and Benjamin Highton. Princeton, NJ: Princeton University Press.

Kinder, Donald R. and Lynn M. Sanders. 1996. Divided by Color. Chicago: University of Chicago Press.

Lawless, Jennifer L. and Richard Logan Fox. 2015. Running from Office: Why Young Americans are Turned Off to Politics. New York: Oxford University Press.

Lax, Jeffrey R., Justin Phillips and Adam Zelizer. 2017. "The Party or the Purse? Unequal Representation in the U.S. Senate.” Working paper, available at https: / / adamzelizer. files.wordpress.com/2016/06/party-or-the-purse.pdf.

Lindblom, Charles E. 1977. Politics and Markets. New York: Basic Books.

Markoff, John. 2005. What the Dormouse Said: How the Sixties Counterculture Shaped the Personal Computer Industry. New York: Penguin.

Page, Benjamin I., Larry M. Bartels and Jason Seawright. 2013. "Democracy and the Policy Preferences of Wealthy Americans.” Perspectives on Politics 11(1):51-73.

Schickler, Eric. 2016. Racial Realignment: The Transformation of American Liberalism, 19321965. Princeton, NJ: Princeton University Press.

Sears, David O. and Carolyn L. Funk. 1999. “Evidence of the Long-Term Persistence of Adults' Political Predispositions.” Journal of Politics 61(1):1-28. 
Shiller, Robert J., Maxim Boycko and Vladimir Korobov. 1990. "Popular Attitudes towards Free Markets: The Soviet Union and the United States Compared." NBER Working Paper, Available at http: //www. nber.org/papers/w3453.

Stenner, Karen. 2005. The Authoritarian Dynamic. New York: Cambridge University Press.

Tesler, Michael. 2012. “The Spillover of Racialization into Health Care: How President Obama Polarized Public Opinion by Racial Attitudes and Race.” American Journal of Political Science 56(3):690-704.

Tesler, Michael. 2015. "Priming Predispositions and Changing Policy Positions: An Account of When Mass Opinion is Primed or Changed." American Journal of Political Science 59(4):806824. 